\title{
FOREWORD
}

\section{Special Issue on Climate Change and Land Conservation and Restoration: Advances in Economics Methods and Policies for Adaptation and Mitigation}

\author{
Sarah Cline and Sahan T. M. Dissanayake
}

\begin{abstract}
Climate change will likely impact the ecosystem services and biodiversity generated from conserved land. Land conservation can also play a significant role in achieving cost-effective mitigation of greenhouse gas emissions. In this special issue we feature seven papers from the 2017 NAREA Workshop, "Climate Change and Land Conservation and Restoration: Advances in Economics Methods and Policies for Adaptation and Mitigation." The articles include papers furthering the methodological frontier; portfolio optimization, dynamic rangeland stocking, and global timber harvest models, and those highlighting innovative applications; climate smart agricultural practices in Nigeria and Vietnam, welfare impacts on birding, and carbon and albedo pricing.
\end{abstract}

Key Words: climate change, land conservation, NAREA, climate adaptation, mitigation

Climate change is the most significant environmental issue of our time and will likely affect ecosystem services generated from conserved land and the distribution, location, and population of many species, altering the ideal geographical boundaries for conservation and restoration (Ando and Hannah 2011, Ando and Mallory 2012, IPCC 2014, Dissanayake and Hennessey 2017). Private and public land conservation and restoration objectives include protection and provision of ecosystem services, and maintenance of functioning ecosystems. Although conservation easements and land preservation programs (i.e., national parks and wilderness areas) have been successful in restricting development and providing ecosystem service benefits in the United States and across the globe, their fixed geographic boundaries create challenges for meeting these objectives in the future.

Sarah Cline, U.S. Department of Agriculture, Washington, D.C., USA and Sahan T. M. Dissanayake, Department of Economics, Portland State University, Portland, USA and IUCN-Sri Lanka, Colombo, Sri Lanka. Correspondence: Sahan T. M. Dissanayake - 1721 SW Broadway - Cramer Hall - Department of Economics - Portland State University - Portland - OR 97201. Phone: +1 217-419-0452. Email: sdissan2@gmail.com, sahan@pdx.edu.

The views expressed here are those of the authors and do not necessarily represent those of the U.S. Department of Agriculture.

Agricultural and Resource Economics Review 47/2 (August 2018) 195-200

(C) The Author(s) 2018. This is an Open Access article, distributed under the terms of the Creative

Commons Attribution licence (http://creativecommons.org/licenses/by/4.0/), which permits unrestricted re-use, distribution, and reproduction in any medium, provided the original work is 
Therefore, it is vital to adapt by considering climate change impacts when making land conservation and restoration choices, to ensure resilience of ecosystem services under changing climate conditions and dynamics (Pressey et al. 2007, Beier and Brost 2010, Ando and Mallory 2012, Polasky et al. 2014).

Managing land use change and preventing deforestation also plays an important role in mitigating climate change. Land conservation and restoration programs have the potential to cost-effectively increase carbon sinks while promoting the dual benefits of protecting ecosystem services and biodiversity (Crowe and Parker 2008). However, there is no clear consensus on the effectiveness of programs to prevent deforestation and restore natural ecosystems or the best land conservation policies to mitigate climate change. Therefore, it is vital to understand cost effective mitigation strategies especially with regard to forests and conservation of other natural lands.

About NAREA: Northeastern Agricultural and Resource Economics Association (NAREA) is a professional association of agricultural and resource economists founded in 1981. The purpose of NAREA is to stimulate and promote education and research on economic and social problems related to the production, marketing, and consumption of agricultural products; natural resource use; the environment, and rural economic development; and the interrelation of the agricultural and rural sectors with the rest of the economy. The Association publishes the Agricultural and Resource Economics Review and holds an annual meeting in June of each year. For more information on the organization and the journal, please visit http://narea.org/.

The 2017 Northeastern Agricultural and Resource Economics Association (NAREA) Workshop, "Climate Change and Land Conservation and Restoration: Advances in Economics Methods and Policies for Adaptation and Mitigation," brought together experts and researchers analyzing climate adaptation and mitigation policies related to public and private land conservation and restoration. The workshop focused on (1) the impact of climate change on ecosystem services generated from U.S. (federal, state, and private) and international land conservation and restoration; (2) the effectiveness and efficiency of mitigating climate change through forest conservation; and (3) adaptive land conservation and restoration methods that account for climate change and the uncertainty inherent in climate projections.

The workshop was organized by Sahan T. M. Dissanayake from Portland State University (previously at Colby College), Sarah Cline from the U.S. Department of Agriculture (previously at the U.S. Department of the Interior), and Jill Caviglia-Harris from Salisbury University, and it was funded by major sponsors USDA-Economic Research Service, and NAREA, and minor sponsors the Institute for Sustainable Solutions (ISS) at Portland State University, and 
the Economics Department, the Environmental Studies Program, and the Goldfarb Center for Public Affairs and Civic Engagement at Colby College.

The workshop was attended by 50 participants and consisted of 14 research presentations (with presenters coming from five continents), three keynote addresses from leading experts: Steve Polasky from the University of Minnesota, Amy Ando from the University of Illinois, and Radley Horton from NASA and the University of Columbia. The workshop also included a policy panel on the future of climate change research featuring Doug Parsons from America Adapts: The Climate Change Podcast and Elli Sparks from Citizens' Climate Lobby.

As a new initiative for the workshop, the organizers created an advisory board to guide the theme and focus of the workshop. The advisory board consisted of Allen Blackman from Resources for the Future, Jonah Busch from the Center for Global Development, Frank Casey from United States Geological Survey, Daniel Hellerstein from USDA-ERS, Elizabeth Schuster from the Nature Conservancy, Shaun Martin from the World Wildlife Fund, Daniela Miteva from Ohio State University, and Lisa Wainger from the University of Maryland. The Workshop Organizers and NAREA gratefully acknowledge the Advisory Board's support and guidance with organizing the Workshop.

In this special issue of Agricultural and Resource Economics Review, we feature seven publications from papers that were presented at the Workshop and subsequently successfully completed the peer review process. The seven publications represent a broad overview of climate change and land conservation and restoration and include papers pushing the methodological frontier and those highlighting innovative applications to consider welfare impacts from climate change.

Ando, Mallory, and Howdaler (2018), "Diversifying to Reduce Conservation Outcome Uncertainty in Multiple Environmental Objectives," first provides an overview of the economics of conservation planning, starting from the early work that emphasized the value of incorporating costs (Ando et al. 1998) to more recent work on conservation models that incorporates temporal dynamics and uncertainty in outcomes (Costello and Polasky 2004, Dissanayake and Onal 2011, and Ando and Mallory 2012). The authors then draw from finance literature and provide new methods for multiple objective optimization, which minimize uncertainty in natural resource conservation settings. The authors demonstrate some features of this approach in a stylized example and end by outlining a typology of correlations among conservation objectives that can help shape intuition about this complex optimization problem in conservation planning.

Favero et al. (2018), "Can the Global Forest Sector Survive $11^{\circ} \mathrm{C}$ Warming?" develops a timber analysis that considers climate change impacts out to the year 2250, exploring a climate change scenario that explores climate change impacts to $11^{\circ} \mathrm{C}$. Modeling shows that global timber supply is to increase through 2250, timber prices will fall, and consumer surplus will increase. 
However, natural forest cover will shrink in the far future, leading to reductions in forests' ability to hold the same carbon stocks as today.

Rautiainen et al. (2018), "Market-level Implications of Regulating Forest Carbon Storage and Albedo for Climate Change Mitigation" uses a marketlevel model to look at regulation through carbon pricing and albedo pricing. The model results show that carbon pricing results in overprovision of climate benefits at the expense of food and timber production. Complementing carbon pricing with albedo pricing reduces welfare losses while it balances welfare gains from carbon sequestration and higher albedo, and therefore, increases welfare. The impacts of both carbon and albedo pricing are sensitive to parameter values such as albedo strength, forest land productivity, and carbon and albedo prices.

Torell and Lee (2018), "Impact of Climate Change on Livestock Returns and Rangeland Ecosystem Sustainability in the Southwest" studies rangeland stocking decisions, given how invasive species risk will change with changing climates. The authors find that livestock stocking rates determined using a simple rule of thumb result in lower forage production, allowable stocking rate, and grazing value than an economically efficient stocking rate. The most important results indicate that projected climate conditions will result in less edible forage and less stable risk of weed invasions on the range. From this, the authors conclude that using ecology and adaptive methods in management will be critical to the sustainability of rangelands.

Kolstoe et al. (2018), "Climate Policy, Land Cover, and Bird Populations: Differential Impacts on the Future Welfare of Birders in the Pacific Northwest" uses citizen science data from eBird to estimate welfare effects for birding trips in the Pacific Northwest. The authors use an enhanced random utility model to develop parameter estimates that are then used to estimate birders' welfare under a climate change scenario. The results show a great deal of heterogeneity in welfare effects across birders in the sample, given forecasted changes in species richness and land cover and each birder's consideration set of birding hotspots.

Two of the papers in the issue study adaptation internationally, with examples from Vietnam and Nigeria. Mishra et al. (2018), "Perception of Climate Change and Impact on Land Allocation and Income: Evidence from Vietnam's Delta Region" examines the effect of the perception of climate change on income and land allocation decisions for smallholder households in Vietnam's Mekong Delta and Red River Delta. Survey results showed a negative and significant impact of climate change perception on income, and that smallholders with a greater perception of climate change allocated less land to paddy crops. The study provides evidence that smallholders make strategic land allocation decisions based on their perceptions of climate change, suggesting that availability of climate information may help smallholder households better plan their coping strategies for the effects of climate change. 
Shittu et al. (2018), "Effects of Land Tenure and Property Rights on Farm Households: Willingness to Accept Incentives to Invest in Measures to Combat Land Degradation in Nigeria" examines the influence of land tenure and property rights on farmers' willingness to accept (WTA) incentives to embrace climate-smart agriculture (CSA) to combat land degradation. The authors use a choice experiment survey conducted among 1138 rural farmers in Nigeria. The study finds that farmers with registered titles expressed positive WTA incentives to embrace CSA and combat land degradation. This paper highlights that land tenure and property rights can play a significant role in climate adaptation.

We conclude this forward to the special issue by thanking the reviewers who provided detailed and thorough comments during the referee process and to the authors for publishing their work and for working within the tight timeline to submit revisions.

\section{References}

Ando, A. W., Camm, J. D., Polasky, S. \& Solow, A. 1998. Species distribution, land values and efficient conservation. Science, 2792, 126-2128.

Ando, A.W., and L. Hannah. 2011. "Lessons From Finance for new Land-Conservation Strategies Given Climate-Change Uncertainty." Conservation Biology 25(2): 412-414.

Ando, A.W., and M.L. Mallory. 2012. "Optimal Portfolio Design to Reduce Climate-Related Conservation Uncertainty in the Prairie Pothole Region." Proceedings of the National Academy of Sciences 109(17): 6484-6489.

Ando, A. W., M.L. Mallory, and A. Howdaler. 2018. "Diversifying to Reduce Conservation Outcome Uncertainty in Multiple Environmental Objectives." Agricultural and Resource Economics Review 47(2): 220-238.

Beier, P., and B. Brost. 2010. "Use of Land Facets to Plan for Climate Change: Conserving the Arenas, not the Actors." Conservation Biology 24(3): 701-710.

Costello, C., and S. Polasky 2004. Dynamic reserve site selection. Resource and Energy Economics, 26, 157-174.

Crowe, K.A., and W.H. Parker. 2008. "Using Portfolio Theory to Guide Reforestation and Restoration Under Climate Change Scenarios." Climate Change 89 (3-4): 355-370.

Dissanayake, S. T. M., and Önal, H. 2011. Amenity Driven Price Effects and Conservation Reserve Site Selection: A Dynamic Linear Integer Programming Approach. Ecological Economics. Vol 70, No 12, 2225.

Dissanayake, S., and M. Hennessey. (2017). Conservation Choices in the Face of Sea-Level Rise: A Case Study on Marsh Migration From Phippsburg, Maine. Agricultural and Resource Economics Review 46(2): 388-419.

Favero 2018. "Can the Global Forest Sector Survive $11^{\circ} \mathrm{C}$ Warming?" Agricultural and Resource Economics Review 47(2): 388-413.

IPCC 2014. Summary for Policymakers. In: Climate Change 2014: Mitigation of Climate Change. Contribution of Working Group III to the Fifth Assessment Report of the Intergovernmental Panel on Climate Change [Edenhofer, O., R. Pichs-Madruga, Y. Sokona, E. Farahani, S. Kadner, K. Seyboth, A. Adler, I. Baum, S. Brunner, P. Eickemeier, B. Kriemann, J. Savolainen, S. Schlömer, C. von Stechow, T. Zwickel and J.C. Minx (eds.)]. Cambridge University Press, Cambridge, United Kingdom and New York, NY, USA.

Kolstoe 2018. "Climate Policy, Land Cover, and Bird Populations: Differential Impacts on the Future Welfare of Birders in the Pacific Northwest." Agricultural and Resource Economics Review 47(2): 272-310. 
Mishra, A 2018. "Perception of Climate Change and Impact on Land Allocation and Income: Evidence from Vietnam's Delta Region" Agricultural and Resource Economics Review 47(2): 311-335.

Polasky, S., D.J. Lewis, A.J. Plantinga, and E. Nelson. 2014. "Implementing the Optimal Provision of Ecosystem Services." Proceedings of the National Academy of Sciences 111 (17): 6248-6253.

Pressey, R.L., M. Cabeza, M.E. Watts, R.M. Cowling, and K.A. Wilson. 2007. "Conservation Planning in a Changing World." Trends in Ecology \& Evolution 22(11): 583-592.

Rautiainen 2018. "Market-level Implications of Regulating Forest Carbon Storage and Albedo for Climate Change Mitigation." Agricultural and Resource Economics Review 47(2): 239271.

Shittu 2018. "Effects of Land Tenure and Property Rights on Farm Households: Willingness to Accept Incentives to Invest in Measures to Combat Land Degradation in Nigeria." Agricultural and Resource Economics Review 47(2): 357-387.

Torell, G. and K. Lee 2018. "Impact of Climate Change on Livestock Returns and Rangeland Ecosystem Sustainability in the Southwest." Agricultural and Resource Economics Review 47(2): 336-356. 